\title{
Brainstem compression by "kissing vertebral arteries"
}

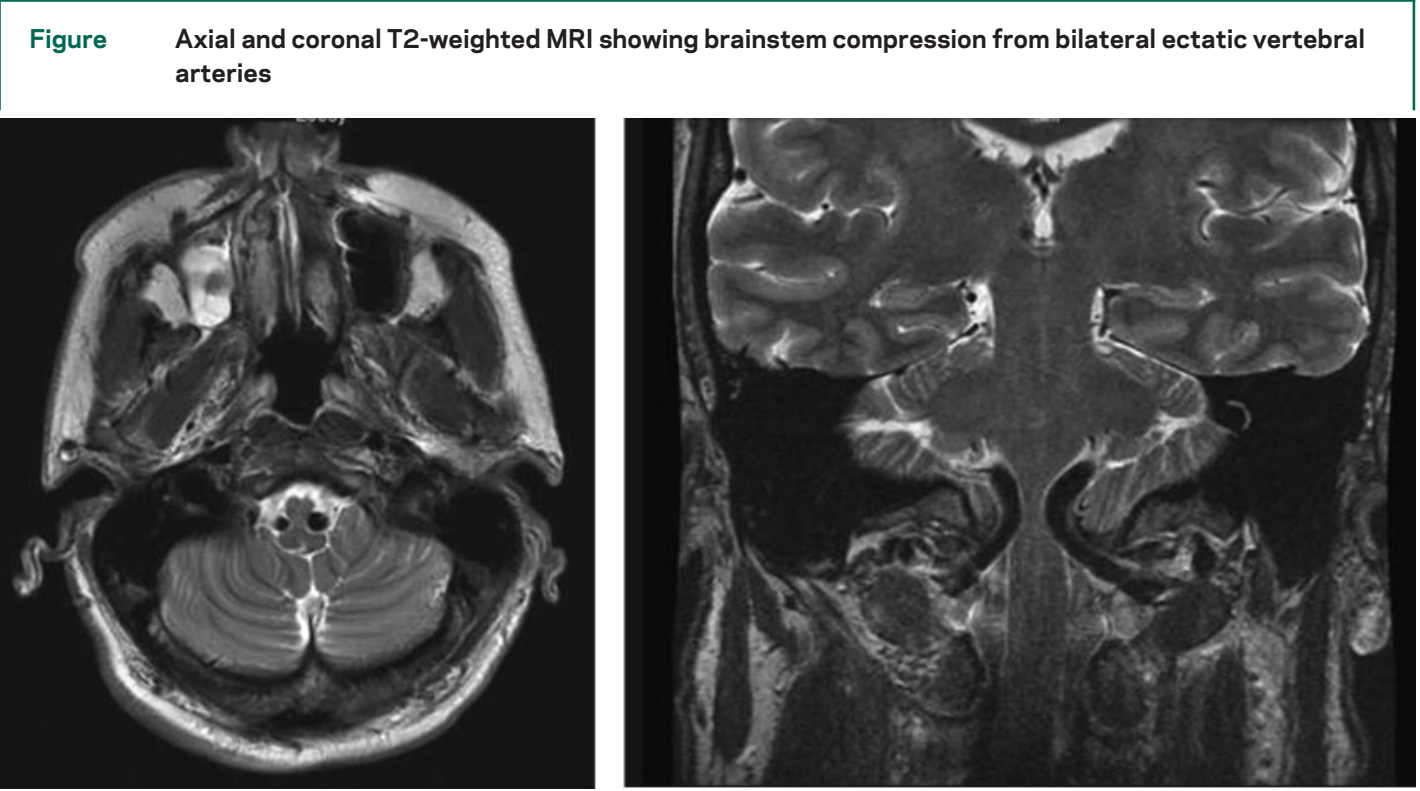

We report a case of brainstem compression from bilateral and enlarged vertebral arteries (VA) in a 55-year-old man with pyramidal tract signs and lower cranial nerve palsy typically seen in this disease process.

Our patient developed dysarthria, dysphagia, and unsteady gait over the previous 2 years. MRI and angiography showed brainstem compression by the VA (figure).

Vascular decompression was performed with the creation of a Gore-tex sling around the VA and subsequent improvement in our patient's symptoms.

Bilateral brainstem compression by "kissing vertebral arteries" is extremely rare. ${ }^{1}$ Brainstem decompression can be achieved with transposition of the VA. ${ }^{2}$

Scott Y. Rahimi, MD, Ahmed R. Shakir, MD, Cargill H. Alleyne, Jr., MD, Augusta, GA

Disclosure: The authors report no disclosures.

Address correspondence and reprint requests to Dr. Scott Y. Rahimi, BI-3088, 1120 15th Street, Department of Neurosurgery, Medical College of Georgia, Augusta, GA 30912; srabimi@mcg.edu

1. Tanaka Y, Miyazaki M, Tsuda M, Matsuyama M, Kuzuhara S. Compression of the medulla oblongata by an elongated vertebral artery. Shinkeinaika 1991;34:335-336.

2. Koyama S. Lower medulla and upper cervical cord compression caused by bilateral vertebral artery. J Neurosurg Spine 2001;94: 337. 


\title{
Neurology
}

\author{
Brainstem compression by "kissing vertebral arteries" \\ Scott Y. Rahimi, Ahmed R. Shakir and Cargill H. Alleyne, Jr \\ Neurology 2008;71;954 \\ DOI 10.1212/01.wnl.0000325997.12607.cd
}

This information is current as of September 15, 2008

\section{Updated Information \& Services}

References

Subspecialty Collections

Permissions \& Licensing

Reprints including high resolution figures, can be found at: http://n.neurology.org/content/71/12/954.full

This article cites 2 articles, 0 of which you can access for free at: http://n.neurology.org/content/71/12/954.full\#ref-list-1

This article, along with others on similar topics, appears in the following collection(s):

\section{All Cerebrovascular disease/Stroke}

http://n.neurology.org/cgi/collection/all_cerebrovascular_disease_strok e

\section{MRI}

http://n.neurology.org/cgi/collection/mri

Other cerebrovascular disease/ Stroke

http://n.neurology.org/cgi/collection/other_cerebrovascular_disease_st roke

Information about reproducing this article in parts (figures,tables) or in its entirety can be found online at:

http://www.neurology.org/about/about_the_journal\#permissions

Information about ordering reprints can be found online:

http://n.neurology.org/subscribers/advertise

Neurology ${ }^{\circledR}$ is the official journal of the American Academy of Neurology. Published continuously since 1951, it is now a weekly with 48 issues per year. Copyright . All rights reserved. Print ISSN: 0028-3878. Online ISSN: 1526-632X.

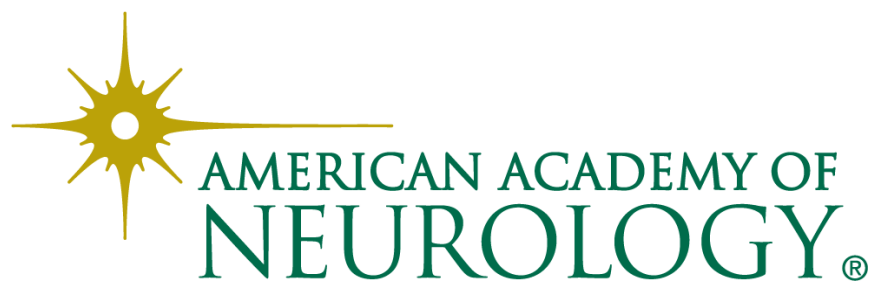

